\title{
Effects of Intercrop Population Density and Row Orientation on Growth and Yields of Sorghum - Cowpea Cropping Systems in Semi Arid Rongai, Kenya
}

\author{
S. M. Karanja ${ }^{1}$, A. M. Kibe ${ }^{1}$, P. N. Karogo ${ }^{2}$ \& Mariam Mwangi ${ }^{1}$ \\ ${ }^{1}$ Department of Crops, Horticulture and Soils, Egerton University, Njoro, Kenya \\ ${ }^{2}$ Department of Civil and Environmental Engineering, Egerton University, Njoro, Kenya \\ Correspondence: A. M. Kibe, Department of Crops, Horticulture and Soils, Egerton University, Njoro, Kenya. \\ Email: akibe@egerton.ac.ke
}

Received: November 7, 2013 Accepted: January 18, 2014 Online Published: April 15, 2014

doi:10.5539/jas.v6n5p34

URL: http://dx.doi.org/10.5539/jas.v6n5p34

\begin{abstract}
Sorghum - cowpea intercropping is an important farming system for small scale farmers in Arid and Semi Arid Lands of sub-Sahara African. Information on the cowpea intercrop population and row orientation effects on growth and yields of sorghum-cowpea cropping systems is however scanty or unavailable for tropical Africa and East African region in particular.With this in mind, a factorial designed experiments was carried out at a farmer's field at Kampi ya Moto, Rongi, Kenya in two seasons i.e. December 2011 - April 2012 Season I (SI) and May-August 2012 Season II (SII). The treatments comprised of sorghum planted at a constant population of 55555 plants/ha and intercropped with cowpea at varying populations of 55 555, 111 111, and 166666 plants/hectare and rows oriented in East-West (E-W) and North-South (N-S) directions, respectively replicated three times. Results showed that increase of cowpea (intercrop) population from 55555 to 166666 plants/ha significantly $(\mathrm{P} \leq 0.05)$ influenced crops growth, grain and yields attributes of both crops. However, there was no significant effect on harvest indices. Intercrop population (cowpea) of 111111 plants/ha produced the highest cowpea grain yields of 214 and $632 \mathrm{~kg} / \mathrm{ha}$ in season I and season II, respectively. The highest sorghum grain yields of $2729 \mathrm{~kg} / \mathrm{ha}$ and 3 $011 \mathrm{~kg} / \mathrm{ha}$ ) were recorded in sole sorghum. The lowest sorghum and cowpea grain yields of 1994.3 and 147.8 $\mathrm{kg} / \mathrm{ha}$ were produced by the highest intercrop cropping system population of 166666 cowpea plants/ha. The E-W row oriented cropping systems produced significantly higher cowpea grain yields ranging from 408 to $973 \mathrm{~kg} / \mathrm{ha}$ compared to 333 to $838 \mathrm{~kg} /$ ha recorded under N-S row orientation. The N-S row orientation however, produced significantly higher sorghum grain yields of 1874 and $2123 \mathrm{~kg} /$ ha from the sole sorghum cropping system in seasons I \& II, respectively. It is recommended that farmers in semi-arid Rongai should intercrop sorghum at 55 555 plants/ha with cowpea at 55555 during the short rainy season of SI (Oct - Dec) and at 111111 plants/ha during the long rainy SII (May - Aug), season, with rows oriented in the E-W direction, in order to realize over $400 \mathrm{~kg} / \mathrm{ha}$ cowpea and $2000 \mathrm{~kg} / \mathrm{ha}$ sorghum grains yields. The higher cowpea intercrop population of $111111 \mathrm{plants} / \mathrm{ha}$ should be used in wetter seasons of semi arid climates.
\end{abstract}

Keywords: intercrop population, row orientation, sorghum, cowpea, ASAL, growth, yields

\section{Introduction}

Kenya, with $75 \%$ of its total land mass of 58.8 million hectares lying within arid and semi arid lands (ASALs), the part of which is the home of up to 10 million, (a quarter of its total) people, is classified as a food deficit country (USAID, 2009). These areas receive low and erratic rainfall ranging between $400-800 \mathrm{~mm} /$ year with high evaporative losses, making moisture a limiting factor for crop production (Harris et al., 2000). The food insecurity situation is further worsened by poor knowledge and access of suitable dry land farming technologies.

In ASAL, land sizes are diminishing due to land subdivision as a result of influx of population from wetter high potential areas. Furthermore, farmers grow crops like maize, beans, sorghum and cowpea as either sole crop or mixed cropping at supra and or sub optimal plant populations with variable row orientations resulting in low yields and frequent crop failure. Under such scenario, adoption of drought tolerant crops i.e. sorghum and cowpea and intercropping systems at optimal population and row orientation can be a plausible technological option for grain food improvement in arid and semi arid areas. 
Intercropping is an agricultural practice of growing two or more crop species simultaneously on the same piece of land (Ofari \& Stern, 1987) and seeks to maximize productivity through diversification (Sullivan, 2003). Other accrued advantages include; effective use of moisture, nutrients and solar radiation (Hussaini et al., 2001), soil and water conservation (Jarenyama et al., 2001), weeds, pests and diseases control (Liebman \& Stover, 2001) and improvement of soil fertility through nitrogen fixation in legume intercrops (Asiwe et al., 2009).

Different experiments on intercrop population in cereal legume intercropping have been conducted by many researchers. Deljoo and Sepehri (2004) reported high land equivalent ratio (1.25) in 2:2 and (1.23) in 1:2 sorghumcowpea row ratios respectively. Similarly, row orientation has been reported to enhance moisture, light and nutrients resource use and consequently yields. According to Fedelibus (2005) experiments done at a latitude of $32^{\circ} \mathrm{S}$ in Australia, results revealed that reducing space between rows or orientating rows to right angles (north-south) to sunlight direction increases weeds shading, water use efficiency and crop yields. Naser and Shamsaddi (2008) field trials on sorghum in Isfahan university, Bam City, Iran at latitude $28^{\circ} \mathrm{S}$ reported an increase in grain yield, 1000 seed weight, dry matter, and number of tillers in high sorghum densities oriented North-South direction.

In Kenya, sorghum is an important food security crop in medium and low altitude regions where maize does poorly and some times fail due to erratic rain or pests and disease attacks (Salasya et al., 1996). It exhibits a wide range of ecological adaptation due to its xerophylic characteristics. It is grown in semi arid areas of Eastern Kenya, Coast, waterlogged and striga stricken areas around Lake Victoria and cold highlands of Rift Valley. The crop performs well in altitude between $500-1700 \mathrm{~m}$ above sea level, with seasonal rainfall of $300 \mathrm{~mm}$ and above. It is grown for grain food and used for a variety of other products like alcohol and livestock feed.

Cowpea is a summer annual legume and grows under extreme drought conditions. It is grown either for vegetable or grains consumption in Kenya (Saidi et al., 2007). Besides its tolerance to moisture stress (Nkongola, 2003), it has other numerous advantages ranging from high nutrition (25\% protein), weed control and soil fertility improvement (Aliu \& Emechembe, 2006). Crop yields in Africa are generally low and depend on plant population, cropping system, cultivars grown and rainfall distribution (Hegstad et al., 1999).

In crop mixtures, competition for growth factors is a major aspect affecting yields (Hauggaard-Nielsen et al., 2006). Interaction between plant population and row orientation influences solar interception by the plant canopy and soil moisture and nutrient uptake by the crops (Tsubo et al., 2003). Therefore, an understanding of these interactions through a study to evaluate the effects of cowpea intercrop populations and row orientation will give us better insight on how best to manipulate plant population under certain rainfall availability by small scale farmers in semi arid regions of Kenya.

\section{Materials and Methods}

\subsection{Site Description}

Afield experiment was conducted at a farmer's field located on grid $0^{\circ} 12^{\prime} \mathrm{N}$ and $35^{\circ} \mathrm{E}$ at Kampi ya Moto location, Rongai District, Nakuru County in Central Rift Valley region of Kenya. The area lies at an altitude of $1768 \mathrm{~m}$ above sea level in low midland zone four (LM 4) agro-ecological zone. As such, it was characterized by hot and dry climate with bimodal rainfall of 500-700 mm between November to January and April/May to August months with wide variation between years. In 2011/12 cropping season, the area received unprecedented higher rainfall of $621 \mathrm{~mm}$ which was poorly distributed during the first season of December 2011-April 2012 and $764 \mathrm{~mm}$ during the second season of May-August 2012. Despite this higher rainfall, the evaporation losses (ETo) were much higher at 860 and $636 \mathrm{~mm}$ over both the respective seasons. Due to this evaporation, the area had a deficit of $96 \mathrm{~mm}$ in SI and marginal excess rain-water of $128 \mathrm{~mm}$ in SII.

The daily average minimum and maximum temperature ranged from $11-15^{\circ} \mathrm{C}$ and $27-30^{\circ} \mathrm{C}$. Soils were classified as mollicandosol developed on sediments of volcanic ashes. The soil was well drained, deep to dark reddish brown friable sandy clay loam soils. It had moderate to high soil fertility, low water holding capacity and good workability .The plant material used in the study was sorghum variety gadam and cowpea machakos 66 (M66) both sourced from Katumani agricultural research station, Kenya.

\subsection{Experimental Design and Layout}

The experiment consisting of 14 treatments had four sole crops, viz sole sorghum (S) spaced at $90 \mathrm{~cm} \times 20 \mathrm{~cm}$ and sole cowpea spaced at $45 \times 20 \mathrm{~cm}(\mathrm{C}), 30 \times 20 \mathrm{~cm}(\mathrm{C} 1)$ and $22.5 \mathrm{~cm} \times 20 \mathrm{~cm}(\mathrm{C} 2)$ and 3 (three) intercrop treatments of sorghum intercropped with cowpea at 55555 (SC) 111,111 (SC1) and 166666 cowpea plants/ha (SC2) in 2 (two) row orientations, East-West (E-W) and North-South (N-S). The cropping systems were planted in 
a factorial arrangement of a randomized complete block design (RCBD) with three replications. The crops were sown simultaneously in both seasons.

At harvest, (i.e. 110 days after planting (DAP) for cowpeas and 150 DAP for sorghum), plants from a net plot area of $2 \mathrm{~m}^{2}$ were uprooted (cowpeas) and stalks cut from the base for sorghum and dried to a constant weight and thrashed to separate the grain from haulms. Data for number of pods per cowpea) and panicle per sorghum plants as well as their test weights were determined. Thereafter, the produce was winnowed, cleaned and weighed to determine grain yields and dry matter (haulm and stover) using a portable electronic scale.

\subsection{Data Analysis}

The data was subjected to analysis of variance (ANOVA). Means were separated using least significant difference and Duncan Multiple Range Test (where interactions occurred) at a probability level of 5\%.

\section{Results and Discussion}

\subsection{Effect of Intercrop Population and Row Orientation on Cowpea Growth and Yield Attributes}

Increasing the cowpea $(C)$ intercrop population density, significantly $(\mathrm{P} \leq 0.05)$ influenced dry matter (haulm) yield of all the sorghum-cowpea cropping systems (Table 2a). Sole cowpea produced higher dry matter yield ranging from 408 to $508 \mathrm{~kg} / \mathrm{ha}$ and 898 to $1430 \mathrm{~kg} / \mathrm{ha}$ in season I and II, respectively. This was attributed to absence of competition and thus, more dry matter accumulation in stem, branches and leaves under sole crop treatments. The results were in agreement with findings by Amedie et al. (2004) in Dharwad, India. Taller cowpea plants were observed under intercropping treatments with intercrop population density of 111111 cowpea plants/ha ( $\mathrm{SC} 1)(21.3 \mathrm{~cm})$ in season I. However, statistically equal $(\mathrm{P}<0.05)$ cowpea heights were observed in the SII (Table 1a). The relatively shorter SI crops were attributed to the more aggressive sorghum crop, which out competed cowpea plants for solar radiation during the water deficit SI period. The Cowpea would however become more competitive in longer (May) season II when rains were more and better distributed and therefore cowpea crop became relatively taller enabling it access the much needed radiation; consequently SII crops were observed to yield more biomass and grain yield than the SI crops.

Cowpea grain yields were also significantly influenced by the intercrop (cowpea) populations. (Table 2a). Intercropping produced significantly lower grain yields ranging from $56 \%-64 \%$ than their corresponding sole crops in season I and II, respectively. The yield reduction in intercropped cowpea was attributed to aggressive effects of sorghum, a $C_{4}$ plant species on cowpea, a $C_{3}$ species. According to Heibsch et al. (1995), crops with $C_{4}$ photosynthetic pathways have been known to be dominant when intercropped with $\mathrm{C}_{3}$ species like cowpea. The shading of cowpea by the taller sorghum plants may also have contributed to reduction on the yields of intercropped cowpea. Egbe (2010) reported that shading by the taller plants in mixture could reduce the photosynthetic rate of the lower growing plants and thereby reduce their yields. The results concurred with findings by Oseni (2006) who reported yield reductions of $65 \%$ in cowpea intercropped with sorghum in 1:1 and 1:2 row proportions, in Bauchi, Nigeria. Increasing cowpea intercrop from 55555 to 111111 plants/ha increased cowpea grain yields to a maximum of $214 \mathrm{~kg} / \mathrm{ha}$ and $632 \mathrm{~kg} / \mathrm{ha}$ before declining to 147 and $499 \mathrm{~kg} / \mathrm{ha}$ at higher intercrop population of 166666 plants/ha (SC2) during drier SI and wetter SII, respectively. Kumar et al. (2000) attributed increased grain yields to increased biomass, number of branches and trifoliate leaves observed under higher populations. However, grain yields reduction beyond an optimal population of $111111 \mathrm{plants} / \mathrm{ha}$ (SC1) was attributed to severe competition for soil moisture, nutrients and solar radiation under the higher cowpea population cropping systems. The results concurred with Egbe (2009) who reported 13\% higher soya seed yield at 333000 plants/ha than that planted at 200000 plants/ha and 400000 plants /ha in sorghum-soybean field experiment in Otobi, Nigeria.

The mean cowpea grain yields from season two were $60 \%$ higher than that obtained from season one (Table 2a). This was attributed to higher and better distributed rainfall of $450 \mathrm{~mm}$ received during may-august 2012 (SII) period compared to low and poorly distributed rainfall of $115.7 \mathrm{~mm}$, received during SI (Dec 2011-April 2012) period (Figure 1 ). Better rains recorded in season II resulted in increased number of branches and trifoliate leaves, and thus increase photosynthesis. The results corroborated the findings by Ndakindemi (2007) who reported a strong positive correlation between biological yields and number of cowpea branches with moisture in semi- arid savannah, Nigeria. 


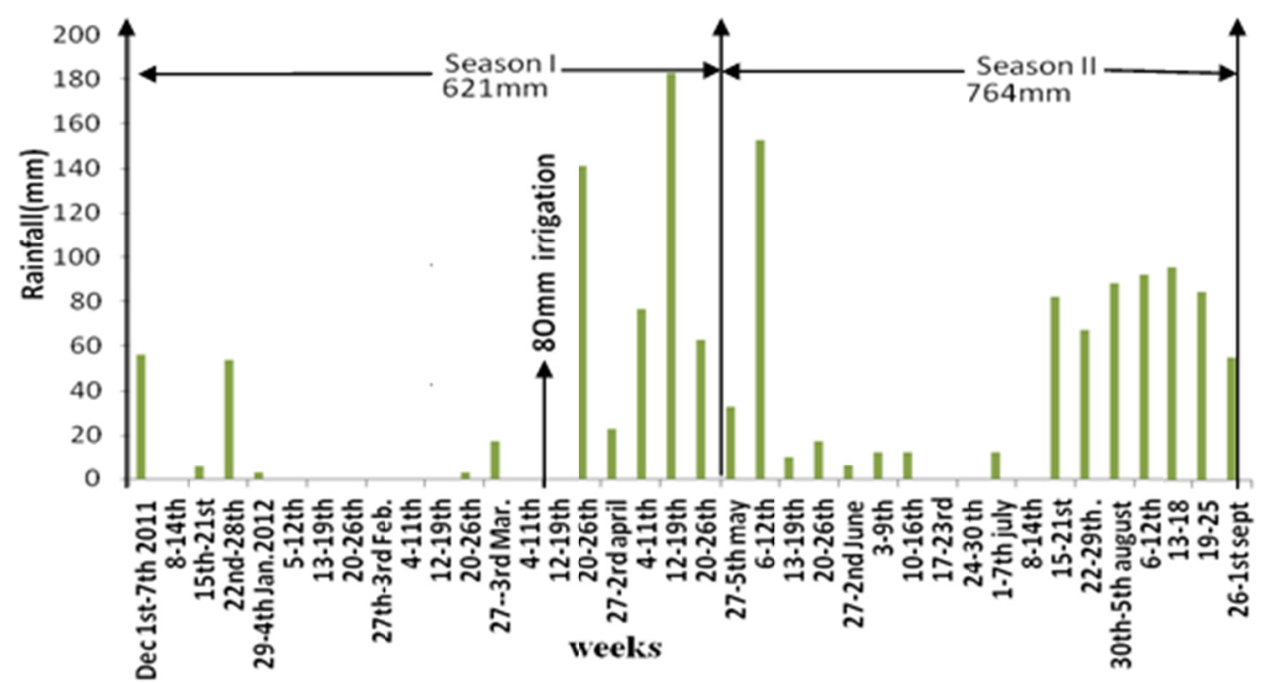

Figure 1. Meteorological weekly rainfall (mm) from December 2011- $1^{\text {st }}$ September 2012 at KampiYa Moto, Rongai

Table 1a. Effect of cowpea (intercrop) population on cowpea height, number pods/plant and grains/pod in sorghum-cowpea cropping systems in Rongai, Kenya in 2011/2012 seasons

\begin{tabular}{lllllll}
\hline Treatments & Cowpea height at & 120 DAP (harvest) & \multicolumn{2}{l}{ Number of Pods/plant } & \multicolumn{2}{l}{ Number of grains/pod } \\
\hline Cropping systems & S1 & SII & SI & SII & S1 & SII \\
C & $15.52 \mathrm{f}$ & $25.12 \mathrm{a}$ & $10.10 \mathrm{a}$ & $13.0 \mathrm{a}$ & $13.6 \mathrm{a}$ & $13.3 \mathrm{a}$ \\
$\mathrm{C} 1$ & $19.55 \mathrm{~b}$ & $25.47 \mathrm{a}$ & $8.2 \mathrm{~b}$ & $7.10 \mathrm{~b}$ & $13.4 \mathrm{a}$ & $12.4 \mathrm{a}$ \\
C2 & $21.23 \mathrm{a}$ & $26.04 \mathrm{a}$ & $3.80 \mathrm{~d}$ & $4.90 \mathrm{~d}$ & $10.9 \mathrm{a}$ & $8.8 \mathrm{c}$ \\
SC & $19.6 \mathrm{~b}$ & $26.23 \mathrm{a}$ & $3.40 \mathrm{~d}$ & $5.20 \mathrm{~d}$ & $10.0 \mathrm{~b}$ & $12.6 \mathrm{a}$ \\
SC1 & $21.3 \mathrm{a}$ & $26.83 \mathrm{a}$ & $4.10 \mathrm{~d}$ & $6.40 \mathrm{c}$ & $9.8 \mathrm{~b}$ & $12.6 \mathrm{a}$ \\
SC2 & $17.27 \mathrm{e}$ & $24.5 \mathrm{a}$ & $2.9 \mathrm{e}$ & $3.50 \mathrm{e}$ & $8.3 \mathrm{~b}$ & $10.0 \mathrm{~b}$ \\
Row Orientation & & & & & & \\
E-W & $18.17 \mathrm{c}$ & $25.55 \mathrm{a}$ & $6.2 \mathrm{c}$ & $6.5 \mathrm{c}$ & $11.8 \mathrm{a}$ & $11.1 \mathrm{a}$ \\
N-S & $18.99 \mathrm{c}$ & $25.85 \mathrm{a}$ & $4.60 \mathrm{~d}$ & $6.8 \mathrm{bc}$ & $10.2 \mathrm{a}$ & $12.1 \mathrm{a}$ \\
SED & 0.49 & 1.37 & 0.6 & 0.2 & 1.5 & 0.4 \\
LSD & 1.02 & 2.85 & 1.15 & 0.5 & 3.1 & 1.0 \\
CV \% & 3.1 & 3.2 & 12.5 & 4.3 & 16.3 & 5 \\
\hline
\end{tabular}

Means within a column followed by the same letter are not significantly different at $\mathrm{P} \leq 0.05$.

Table 1b. Interaction effect of cowpea (intercrop) population and row orientation on Pods/plant and grain/pod of cowpea in sorghum-cowpea cropping systems in Rongai, Kenya in 2011/2012 seasons

\begin{tabular}{lcccccccc}
\hline \multirow{2}{*}{ Treatments } & \multicolumn{4}{c}{ Number of pods/plant } & \multicolumn{3}{c}{ Number grains/p Number of grains/pod } \\
& \multicolumn{3}{c}{ Row Orientation } & \multicolumn{3}{c}{ Row Orientation } \\
\hline Cropping Systems & E-W & N-S & E-W & N-S & E-W & N-S & E-W & N-S \\
C & $12.6 \mathrm{a}$ & $4.6 \mathrm{~cd}$ & $13 \mathrm{a}$ & $13 \mathrm{a}$ & $13.7 \mathrm{a}$ & $13.4 \mathrm{a}$ & $13.5 \mathrm{a}$ & $13 \mathrm{a}$ \\
$\mathrm{C} 1$ & $10.6 \mathrm{~b}$ & $5.8 \mathrm{c}$ & $7.6 \mathrm{~b}$ & $6.5 \mathrm{~b}$ & $13.4 \mathrm{a}$ & $13.3 \mathrm{a}$ & $11.8 \mathrm{~b}$ & $13 \mathrm{a}$ \\
$\mathrm{C} 2$ & $3.2 \mathrm{e}$ & $4.47 \mathrm{~d}$ & $6.9 \mathrm{~b}$ & $5.8 \mathrm{c}$ & $9.8 \mathrm{bc}$ & $12 \mathrm{a}$ & $8.5 \mathrm{c}$ & $9.2 \mathrm{c}$ \\
SC & $3.8 \mathrm{e}$ & $3.0 \mathrm{e}$ & $5.8 \mathrm{c}$ & $4.6 \mathrm{e}$ & $11.3 \mathrm{a}$ & $8.6 \mathrm{c}$ & $12.7 \mathrm{a}$ & $12.5 \mathrm{ab}$ \\
SC1 & $4.1 \mathrm{de}$ & $4 \mathrm{~d}$ & $7.5 \mathrm{~b}$ & $5.2 \mathrm{~d}$ & $11.6 \mathrm{ab}$ & $8 \mathrm{~cd}$ & $11.5 \mathrm{~b}$ & $13.4 \mathrm{a}$ \\
SC2 & $3.1 \mathrm{~d}$ & $2.6 \mathrm{~b}$ & $3.6 \mathrm{f}$ & $3.4 \mathrm{f}$ & $10.7 \mathrm{~b}$ & $6 \mathrm{~d}$ & $8.6 \mathrm{c}$ & $11.3 \mathrm{~b}$ \\
SED & 0.38 & 0.16 & \multicolumn{2}{c}{1.02} & \multicolumn{2}{c}{0.33} \\
DMRT & 1.17 & 0.51 & \multicolumn{2}{c}{3.08} & & \multicolumn{2}{c}{1.04}
\end{tabular}

Means within a column and row followed by same letter in any season are not significantly different at $\mathrm{P} \leq 0.05$. 
Table 2a. Effect of cowpea (intercrop) population on cowpea grain, haulm yields and harvest index of cowpea in sorghum-cowpea cropping systems in Rongai, Kenya during 2011/2012 seasons

\begin{tabular}{lcccccc}
\hline Treatments & \multicolumn{2}{c}{ Cowpea grains yield (kg/ha) } & \multicolumn{2}{c}{ Haulms yield (Kg/ha) } & \multicolumn{2}{c}{ Harvest index } \\
Cropping systems & S1 & SII & S1 & SII & S1 & SII \\
\hline C & $461.8 \mathrm{c}$ & $1139.80 \mathrm{c}$ & $408 \mathrm{a}$ & $898 \mathrm{~cd}$ & $0.53 \mathrm{a}$ & $0.56 \mathrm{a}$ \\
$\mathrm{C} 1$ & $563.3 \mathrm{~b}$ & $1273.3 \mathrm{~b}$ & $483 \mathrm{a}$ & $1267 \mathrm{~b}$ & $0.54 \mathrm{a}$ & $0.50 \mathrm{~b}$ \\
$\mathrm{C} 2$ & $658.20 \mathrm{a}$ & $1373.7 \mathrm{a}$ & $508 \mathrm{a}$ & $1430 \mathrm{a}$ & $0.57 \mathrm{a}$ & $0.48 \mathrm{bc}$ \\
$\mathrm{SC}$ & $180.2 \mathrm{~g}$ & $516.7 \mathrm{~g}$ & $308 \mathrm{~b}$ & $707 \mathrm{~d}$ & $0.38 \mathrm{~b}$ & $0.42 \mathrm{~d}$ \\
$\mathrm{SC} 1$ & $214 \mathrm{f}$ & $632 \mathrm{f}$ & $333 \mathrm{~b}$ & $732 \mathrm{~d}$ & $0.39 \mathrm{~b}$ & $0.43 \mathrm{~cd}$ \\
SC2 & $147.8 \mathrm{~h}$ & $499.5 \mathrm{~h}$ & $350 \mathrm{~b}$ & $984 \mathrm{~d}$ & $0.29 \mathrm{c}$ & $0.33 \mathrm{e}$ \\
Row Orientation & & & & & & \\
E-W & $408 \mathrm{~d}$ & $973 \mathrm{~d}$ & $431 \mathrm{~b}$ & $1003 \mathrm{c}$ & $0.45 \mathrm{~b}$ & $0.49 \mathrm{bc}$ \\
N-S & $333 \mathrm{e}$ & $838.4 \mathrm{e}$ & $36 \mathrm{~b}$ & $999 \mathrm{~cd}$ & $0.44 \mathrm{~b}$ & $0.45 \mathrm{c}$ \\
SED & 14.78 & 44.5 & 68.7 & 58.5 & 0.04 & 0.022 \\
LSD & 30.64 & 92.29 & 142.4 & 122 & 0.09 & 0.05 \\
CV\% & 5.0 & 7.2 & 21.1 & 7.2 & 11.1 & 5.9 \\
\hline
\end{tabular}

Means within a column followed by the same letter are not significantly different at $\mathrm{P} \leq 0.05$.

Table $2 b$. Interaction effect of cowpea ( intercrop) population and row orientation on cowpea grain yields, haulm and harvest index in sorghum- cowpea cropping systems in 2011/12 seasons

\begin{tabular}{|c|c|c|c|c|c|c|c|c|c|c|c|c|}
\hline \multirow{4}{*}{$\begin{array}{l}\text { Treatments } \\
\text { Cropping } \\
\text { systems }\end{array}$} & \multirow{2}{*}{\multicolumn{4}{|c|}{$\begin{array}{l}\text { Grain yield(kg/ha) } \\
\text { Row Orientation }\end{array}$}} & \multirow{2}{*}{\multicolumn{4}{|c|}{$\begin{array}{l}\text { Haulm yields }(\mathrm{kg} / \mathrm{ha}) \\
\text { Row Orientation }\end{array}$}} & \multirow{2}{*}{\multicolumn{4}{|c|}{$\begin{array}{l}\text { Cowpea Harvest indices } \\
\text { Row Orientation }\end{array}$}} \\
\hline & & & & & & & & & & & & \\
\hline & \multicolumn{2}{|c|}{ SI } & \multicolumn{2}{|c|}{ SII } & \multicolumn{2}{|c|}{ SI } & \multicolumn{2}{|c|}{ SII } & \multicolumn{2}{|c|}{ SI } & \multicolumn{2}{|c|}{ SII } \\
\hline & E-W & $\mathrm{N}-\mathrm{S}$ & E-W & N-S & E-W & $\mathrm{N}-\mathrm{S}$ & E-W & N-S & E-W & $\mathrm{N}-\mathrm{S}$ & E-W & $\mathrm{N}-\mathrm{S}$ \\
\hline $\mathrm{C}$ & $406.9 \mathrm{c}$ & $335.4 \mathrm{~d}$ & $1166.7 \mathrm{c}$ & $1116.7 \mathrm{c}$ & $450 \mathrm{a}$ & $367 \mathrm{~b}$ & $948 \mathrm{~d}$ & 849de & $0.53 a$ & $0.54 \mathrm{a}$ & $0.55 \mathrm{a}$ & $0.56 \mathrm{a}$ \\
\hline $\mathrm{C} 1$ & $500.7 \mathrm{~b}$ & $423 c$ & $1566.7 \mathrm{a}$ & $1166.7 \mathrm{c}$ & $533 a$ & 433ab & $1470 \mathrm{a}$ & $1043 c$ & $0.54 \mathrm{a}$ & $0.54 \mathrm{a}$ & $0.52 \mathrm{a}$ & $0.52 \mathrm{a}$ \\
\hline C2 & $636 a$ & $499.7 b$ & $1433.3 \mathrm{a}$ & $1233.3 \mathrm{~b}$ & $567 \mathrm{a}$ & $450 \mathrm{a}$ & $1353 b$ & $1506 a$ & $0.56 \mathrm{a}$ & $0.56 \mathrm{a}$ & $0.51 \mathrm{a}$ & $0.45 \mathrm{a}$ \\
\hline $\mathrm{SC}$ & $192.3 \mathrm{e}$ & $172 . .7 \mathrm{f}$ & $566.7 \mathrm{e}$ & $450 \mathrm{f}$ & $300 \mathrm{~b}$ & $317 \mathrm{~b}$ & $594 \mathrm{f}$ & $819 \mathrm{e}$ & $0.37 \mathrm{~b}$ & $0.38 \mathrm{~b}$ & $0.48 \mathrm{a}$ & $0.35 b$ \\
\hline $\mathrm{SC} 1$ & $225 d$ & $204 d$ & $583.3 \mathrm{e}$ & $600 \mathrm{e}$ & $267 \mathrm{c}$ & 400ab & $631 \mathrm{f}$ & $833 \mathrm{e}$ & $0.36 \mathrm{~b}$ & $0.38 \mathrm{~b}$ & $0.48 \mathrm{a}$ & $0.42 \mathrm{ab}$ \\
\hline $\mathrm{SC} 2$ & $180.3 \mathrm{e}$ & $105.7 f$ & $716.7 d$ & $483.3 d$ & $333 b$ & $367 \mathrm{~b}$ & $1023 \mathrm{~cd}$ & $945 \mathrm{~d}$ & $0.37 \mathrm{~b}$ & $0.33 b$ & $0.41 \mathrm{a}$ & $0.33 b$ \\
\hline SED & 10 & 0.3 & 31 & & & 8.6 & 41. & & 0.0 & 29 & & 048 \\
\hline DMRT & 30 & .2 & 90 & & & 7.1 & 120 & & $0 .($ & 09 & & 16 \\
\hline
\end{tabular}

Means within a column and row followed by same letter in any season are not significantly different at $\mathrm{P} \leq 0.05$.

The variation in cowpea grain yields was also attributed to yield attributes (Table 1a). According to Muhammed et al. (2009), legume grain yields relates positively with number of pods/pod. However, this relationship is influenced by the plant population of a cropping system. From the current study, the number of pods/plant increased by $17 \%$ and $19 \%$ after increasing intercrop population densities from 55555 to 111111 plants/ha in season 1 and season II, respectively (Table 1a). The results corresponded with those of Subian and Selvarajan (2000) and Kumar (2007) who reported 12\% increase in pods/plant of soya bean grown as intercrop with sorghum in one and two row proportions in Tamil Nadu, India.

The economic yield of a cropping system is determined by the harvest index (HI) (ratio of grain yield to above ground biomass). The higher the HI, the higher the dry matter conversion efficiency. In the present study, no significant difference in cowpea harvest indices were observed by increasing intercrop population density from 
55555 to 111111 plants/ha. However, there was a significantly decline in HI at 166666 plants/ha (Table 2a). Similar observations were reported by Haseeb-ur-Rehman et al. (2010) and Egbe et al. (2010). The reduction in cowpea harvest index above the optimal intercrop population of 111111 plants/ha (SC1) was attributed to sorghum shading effects on cowpea, which caused the legume component to allocate more photosynthates to vegetative growth and thus height so as to compete with the taller sorghum and thus, have access to more solar radiation. The results were in agreement with findings by Matusso et al. (2013) for a maize- soya intercropping system in Embu, Kenya.

Row orientation also significantly $(\mathrm{P} \leq 0.05)$ influenced cowpea grain yield (Table 2a). The East to West $(\mathrm{E}-\mathrm{W})$ row orientated crops gave up to $18.3 \%$ and $13.9 \%$ higher cowpea grain yields than the North to South (N-S) oriented crops in both seasons, respectively. This was in agreement with observations made by Tsuboet al., (2003) who concluded that E-W row oriented crops allowed shorter intercrop (beans) between tall maize to receive higher photosynthetic active radiation (PAR) than N-S in maize -beans field experiments in semi arid conditions of Free State University, South Africa.

The intercrop population and row orientation interaction effects significantly $(\mathrm{P}<0.05)$ influenced the number of pods/plant, grains/pod and consequently grain yields (Table 1b, 2b). The E-W: 55555 and E-W: 111111 plants/ha populations, produced the highest pods/plant ranging from 3.8 to 7.5 and cowpea grain yields ranging from 225 and $583 \mathrm{~kg} / \mathrm{ha}$ in the SI and SII season, respectively.

It can be concluded that farmers in Rongai should plant cowpea intercrop in sorghum at populations ranging from 55555 to 111111 plants/ha under the E-W row orientation to allow more light penetration and interception. This would enhance higher photosynthesis by cowpea and ultimately produce better yields that would vary depending on amount of incident rainfall.

\subsection{Effect of Intercrop Population on Sorghum Growth Grain and Yields Attributes}

Among the cropping systems, sole sorghum recorded the tallest plants of $99.1 \mathrm{~cm}$ and $104.3 \mathrm{~cm}$ compared to intercropping systems (Table 3). Sorghum intercropped with cowpea at 166,666plants/ha recorded the shortest plants of 83.7 and $88.1 \mathrm{~cm}$ in season I and II, respectively. Egbe (2010) attributed reduced growth to competition for soil moisture, nutrients and solar radiation in higher population crop mixtures. Similar findings were also reported by Anil kumar (2007) in field experiment done in Daward, India.

Differential response of sorghum to intercrop (cowpea) population with respect to yield attributes such as ear length and ear weight was noted between seasons (Table 3). In the present study, increasing intercrop density from 55,555 to 111,111 plants/ha increased sorghum ear length by $2.7 \%$ and $2 \%$ and ear weight by $4 \%$ and $8.6 \%$ in season I and II, respectively. However, beyond critical intercrop density of 166,666 plants/ha (SC2), sorghum yield attributes declined significantly. The results concurred with Oseni (2006) findings in Bauchi, Nigeria.

Table 3. Effect of intercrop population on sorghum height, length of ear, ear weight in sorghum-cowpea cropping systems in Rongai, Kenya in 2011/2012

\begin{tabular}{lcccccc}
\hline Treatments & \multicolumn{2}{l}{ Sorghum height at harvest (150 DAP) } & \multicolumn{2}{l}{ Length of ear/plant (cm) } & \multicolumn{3}{l}{ Weight of ear/plant $(\mathrm{g})$} \\
Cropping systems & S1 & SII & S1 & SII & S1 & SII \\
\hline S & $99.1 \mathrm{a}$ & $104.3 \mathrm{a}$ & $17.86 \mathrm{a}$ & $17.92 \mathrm{a}$ & $92.04 \mathrm{a}$ & $92.15 \mathrm{a}$ \\
SC & $88.6 \mathrm{c}$ & $90.3 \mathrm{c}$ & $16.88 \mathrm{~b}$ & $17.52 \mathrm{a}$ & $67.62 \mathrm{~d}$ & $68.17 \mathrm{e}$ \\
SC1 & $86.6 \mathrm{~d}$ & $89.3 \mathrm{~d}$ & $17.35 \mathrm{ab}$ & $17.88 \mathrm{a}$ & $71.05 \mathrm{c}$ & $74.61 \mathrm{c}$ \\
SC2 & $83.7 \mathrm{e}$ & $88.1 \mathrm{e}$ & $16.52 \mathrm{~b}$ & $17.12 \mathrm{~b}$ & $62.26 \mathrm{e}$ & $65.77 \mathrm{f}$ \\
Row orientation & & & & & & \\
E-W & $86.9 \mathrm{~d}$ & $86.6 \mathrm{~b}$ & $16.47 \mathrm{~b}$ & $17.21 \mathrm{~b}$ & $70.66 \mathrm{c}$ & $71.01 \mathrm{~d}$ \\
N-S & $92.1 \mathrm{~b}$ & $94.7 \mathrm{~b}$ & $17.83 \mathrm{a}$ & $18.02 \mathrm{a}$ & $77.33 \mathrm{~b}$ & $79.28 \mathrm{~b}$ \\
SED & 0.93 & 0.47 & 0.36 & 0.26 & 1.73 & 0.57 \\
LSD & 1.98 & 1 & 0.76 & 0.56 & 3.70 & 1.23 \\
CV \% & 1.3 & 0.6 & 4 & 5.3 & 7 & 6.4 \\
\hline
\end{tabular}

Means within a column followed by the same letter are not significantly different at $\mathrm{P} \leq 0.05$. 
Table 4a. Effect of cowpea (intercrop) population on sorghum grain yield, stover yield, harvest index in sorghum-cowpea cropping systems in Rongai, Kenya in 2011/2012 seasons

\begin{tabular}{lcccccc}
\hline Treatments & \multicolumn{2}{c}{ Grain yield(kg/ha) } & \multicolumn{2}{c}{ Stover weight $(\mathrm{kg} / \mathrm{ha})$} & \multicolumn{2}{c}{ Sorghum Harvest indeces } \\
Cropping systems & S1 & SII & S1 & SII & S1 & SII \\
\hline S & $2729.3 \mathrm{a}$ & $3011 \mathrm{a}$ & $1817.2 \mathrm{c}$ & $1923 \mathrm{~b}$ & $0.6 \mathrm{a}$ & $0.60 \mathrm{a}$ \\
SC & $2292.8 \mathrm{~d}$ & $2138 \mathrm{~d}$ & $1810 \mathrm{c}$ & $2033 \mathrm{a}$ & $0.56 \mathrm{bc}$ & $0.51 \mathrm{~b}$ \\
SC1 & $2409 \mathrm{c}$ & $2240.7 \mathrm{c}$ & $1839 \mathrm{~b}$ & $2022 \mathrm{a}$ & $0.57 \mathrm{~b}$ & $0.52 \mathrm{~b}$ \\
SC2 & $2160 \mathrm{e}$ & $1865.8 \mathrm{e}$ & $1939.3 \mathrm{a}$ & $2152 \mathrm{a}$ & $0.53 \mathrm{c}$ & $0.47 \mathrm{c}$ \\
Row orientation & & & & & & \\
E-W & $2292.9 \mathrm{~d}$ & $2239.6 \mathrm{c}$ & $1828.3 \mathrm{~b}$ & $1942 \mathrm{~b}$ & $0.56 \mathrm{~b}$ & $0.53 \mathrm{a}$ \\
N-S & $2503 \mathrm{~b}$ & $2388 \mathrm{~b}$ & $1874 \mathrm{~b}$ & $2123 \mathrm{a}$ & $0.53 \mathrm{c}$ & $0.53 \mathrm{a}$ \\
SED & 29.52 & 32.39 & 23.08 & 76.5 & 0.01 & 0.12 \\
LSD & 63.3 & 69.47 & 49.28 & 164.2 & 0.02 & 0.25 \\
CV \% & 6 & 6.5 & 1.4 & 4.6 & 1 & 2.7 \\
\hline
\end{tabular}

Means within a column followed by the same letter are not significantly different at $\mathrm{P} \leq 0.05$.

Table 4b. Interaction effect of intercrop population and row orientation on stover yield and grain yield in sorghumcowpea cropping systems in 2011/12 during season I and II in Rongai, Kenya

\begin{tabular}{|c|c|c|c|c|c|c|c|c|}
\hline \multirow{4}{*}{$\begin{array}{l}\text { Treatments } \\
\text { Cropping systems }\end{array}$} & \multicolumn{4}{|c|}{ Stover yields(kg/ha) } & \multicolumn{4}{|c|}{ Grain yield(kg/ha) } \\
\hline & \multicolumn{4}{|c|}{ Row Orientation } & \multicolumn{4}{|c|}{ Row Orientation } \\
\hline & \multicolumn{2}{|c|}{ SI } & \multicolumn{2}{|c|}{ SII } & \multicolumn{2}{|c|}{ SI } & \multicolumn{2}{|c|}{ SII } \\
\hline & E-W & N-S & E-W & $\mathrm{N}-\mathrm{S}$ & E-W & N-S & E-W & N-S \\
\hline $\mathrm{S}$ & $2663.3 b$ & $2974.3 \mathrm{a}$ & $1884 \mathrm{c}$ & $1961 \mathrm{c}$ & $2663.3 b$ & $2795.3 \mathrm{a}$ & $2974.3 b$ & $3048.0 \mathrm{a}$ \\
\hline $\mathrm{SC}$ & $1864 d$ & $1891.3 d$ & $1893 \mathrm{c}$ & $2172 \mathrm{ab}$ & $2183.7 \mathrm{f}$ & $2402 d$ & $2090.7 \mathrm{e}$ & $2185.7 \mathrm{~d}$ \\
\hline $\mathrm{SC} 1$ & $1918 \mathrm{~cd}$ & $1922 c$ & $1949 c$ & $2091 \mathrm{a}$ & $2330.3 \mathrm{de}$ & $2488 \mathrm{c}$ & $2076 \mathrm{e}$ & $2405 \mathrm{c}$ \\
\hline $\mathrm{SC} 2$ & $1946 c$ & $1932 c$ & $2042 b c$ & $2263 a$ & $1994.3 \mathrm{~g}$ & $2327 \mathrm{e}$ & $1817 f$ & $1914 \mathrm{e}$ \\
\hline SED & \multicolumn{2}{|c|}{16.49} & \multicolumn{2}{|c|}{76.5} & \multicolumn{2}{|c|}{20.87} & \multicolumn{2}{|c|}{22.91} \\
\hline DMRT & \multicolumn{2}{|c|}{48.64} & \multicolumn{2}{|c|}{164.2} & \multicolumn{2}{|c|}{63.24} & \multicolumn{2}{|c|}{69.41} \\
\hline
\end{tabular}

Means within a column and row followed by same letter in any season are not significantly different at $\mathrm{P} \leq 0.05$.

Intercrop (cowpea) population also significantly $(\mathrm{P} \leq 0.05)$ influenced sorghum grain yields $($ Table $4 a)$. Sole sorghum produced the highest grain yields $(2729 \mathrm{~kg} / \mathrm{ha}$ and $3011 \mathrm{~kg} / \mathrm{ha})$ than the intercropping treatments in both the respective seasons. Similarly, Oseni (2006) had earlier reported higher grain yields $(3715 \mathrm{~kg} / \mathrm{ha}) \mathrm{in} \mathrm{sole}$ sorghum treatments. In the present study, sorghum grain yields increased by $5 \%$ i.e., $117 \mathrm{~kg} / \mathrm{ha}$ and $4.7 \%$ (i.e., 102 $\mathrm{kg} / \mathrm{ha}$ ) by increasing cowpea density from 55555 to 111111 plants/ha in SI and SII, respectively (Table 4a). The results concurred with Raghuwanshi et al. (2002) who reported a 19\% increase in maize grain yields when two rows of beans were planted between two rows of maize. Cessman (2001) reported reduced soil surface evaporation and run-off associated with increased legume intercrop, which increased water storage for crop use. Therefore, the better moisture conservation occasioned by higher cowpea density could have contributed to the intercrop accessing higher soil moisture that resulted into increased sorghum yields at 111111 plants/ha (SC1) treatments. Increasing the cowpea intercrop density to 166666 plants/ha (SC2), caused sorghum grain yields to decline significantly $(\mathrm{p} \leq 0.05$ ) by 10 and $16 \%$ SI and SII, respectively (Table $4 \mathrm{a}$ ). These observations corresponded to reports by Silwana and Lucas (2002) who recorded 34\% and 19\% reduction in maize grain yields with increasing bean population to 120000 plants/ha, in Transkei, South Africa. Therefore, the yield reduction was attributed to severe competition for moisture, nutrients and solar radiation associated with higherpopulation's densities beyond the optimal cowpea density of $111111 \mathrm{plants} / \mathrm{ha}$. 
In the current study, over 70\% (approximately $450 \mathrm{~mm}$ ) of total rainfall received in Dec 2011-April 2012 (Season I) came late and fell between flowering and grain filling stage of sorghum. Therefore, the relatively low and poorly distributed rainfall over the vegetative phase and good rains during the reproductive stage was responsible for the slightly lower grain yields of $2729 \mathrm{~kg} / \mathrm{ha}$ in season I as compared to $3011 \mathrm{~kg} / \mathrm{ha}$ in season II (Table $4 \mathrm{a}$ ). In the vegetative phase, better rainfall and good distribution would have improved plants growth only and thus dry matter accumulation (Kumar et al., 2000; Muhammed et al., 2009). Similarly, Harris et al. (2000) also reported of a strong correlation between sorghum grain yields and moisture availability at the critical reproductive stage.

The efficiency of a crop to convert dry matter to economic yield is determined by the harvest index. The harvest index of sorghum was not influenced $(\mathrm{P} \leq 0.05)$ by the intercrop population density (Table $4 \mathrm{a})$. Sole sorghum recorded the highest harvest index (0.6) in both seasons. Increasing in intercrop density from 55 555, 111111 and 166666 plants/ha recorded statistically $(\mathrm{P} \leq 0.05)$ equal harvest indices ranging from 0.47 to 0.57 in both seasons. The results concurred with findings by Saleem et al. (2011) in maize-legume intercropping systems in Eastern regions of Kenya

Row orientation significantly $(\mathrm{P} \leq 0.05)$ influenced growth and yield attributes of sorghum intercropped with cowpea (Table 4a). Taller sorghum plants of 92.1 and $94.7 \mathrm{~cm}$ were observed in cropping systems oriented in N-S compared to 86.9 and $86.6 \mathrm{~cm}$ observed in E-W orientation in SI and SII, respectively. Sorghum with relatively higher ear length $(17.33$ and $18.02 \mathrm{~cm})$, ear weight/plant $(77.37$ and $79.29 \mathrm{~g})$ and grain yields $(2503$ and 2388 $\mathrm{kg} / \mathrm{ha}$ ) were observed in N-S row arrangements as compared to E-W row treatments in both seasons. The results collaborates findings by Tsubo et al. (2003) who reported that maize crops oriented in N-S row arrangements intercepted more PAR, increasing rate of photosynthesis and thereby increasing ear length, ear weight and grain yields in maize-beans intercrop experiments in Semi-arid conditions of South Africa. Therefore, farmers should plant sole sorghum in N-S row orientation but in E-W orientation under sorghum-cowpea intercropping systems for increased cowpea grain yields.

Interactive effects of intercrop population and row orientation significantly influenced sorghum grain and dry matter (stover) yields in both seasons (Table 4b). Increasing cowpea density from 55555 to 166666 plants/ha produced significantly higher grain yields ranging from 2327 to $2488 \mathrm{~kg} / \mathrm{ha}$ in N-S compared to $1994-2300 \mathrm{~kg} / \mathrm{ha}$ recorded in E-W row oriented crops during the first season. Generally, N-S oriented crops produced significantly higher sorghum grain and stover yields than E-W oriented intercrop systems in both seasons (Table $4 \mathrm{~b}$ ). This was attributed to more solar radiation interception by the taller sorghum plants resulting to increased photosynthesis and consequently more dry matter and grain yields production.

\section{References}

Akbar \& Khan. (2002). Effect of row orientation on yield of maize in Pakistan. Journal of Agricultural Resource, 17.

Aliyu, B. S., \& Emechebe, A. M. (2006). Effect of intra and inter row mixing of sorghum with two varieties of cowpea on host crop yield in striaga infested field. Agricultural Journal Res, 1, 24- 26.

Amedie, B., Chittapur, B. M., Halikatti, S. I., \& Chimmad, V. P. (2010). Intercropping of Grain Legumes in Sorghum. Karnataka Journal of Agricultural Sciences, 17(1), 22-27.

Anikumar. (2007). Effects of legumes on growth, yield and quality of pop sorghum in inter and mixed cropping systems. MSc Thesis. College of Agriculture, Dharwad.

Asiwe, J. A., Belane, N., \& Dekora, F. D. (2009). Evaluation of cowpea breeding lines for Nitrogen fixation at ARC Grain crops Potchestroom, South Africa. $16^{\text {th }}$ International congress on biological nitrogen fixation. USA, June 2009.

Borger, P. D. C, Hashem, A., \& Pathan. S. (2010). Manipulating crop row orientation to suppressweeds and increase crop yield. Weed Science, (58), 174-178. http://dx.doi.org/10.1614/WS-09-094.1

Cesssman, K. G. (2001). Crop science Research to ensure food security. In Nesbergera.crop science progress and prospects (pp. 33-51)

Deljoo, A., \& Sepehri (2004). Evaluation of sowing pattern on growth indices and yield in Grain sorghum intercropping systems. $8^{\text {th }}$ Agronomy and plant breeding national congress. Iran.

Egbe, O. M. (2009). Effects of Plant density of intercropped soyabean with tall sorghum on competitive ability of soya bean and economic yield at Otobi Bevenue, Nigeria. ARPN Journal of Agricultural and biological science, 4, 54-65. 
Egbe, O., Alibo, S. E., \& Nwueze, I. (2010). Evaluation of some early maturing cowpea varieties for intercropping with maize in southern Guinea, Nigeria. Agric. Bio J. N A, 1(5), 845-858.

Fedelibus, M. (2005). Grapevine row orientation offers light environment, growth and development of black night shade (solanumnigram). Weed science, 53, 802-812. http://dx.doi.org/10.1614/WS-04-181R1.1

Haseeb-ur, A. A., Muhammad, W., \& Zamir, M. S. (2010). Impact of nitrogen application on growth and yields of maize grown alone and intercropped with cowpea. J. Agric enviro. Sci, 7(10), 43-47

Hauggaard-Nielsen, H., Andersen, M. K., \& Jensen, E. S. (2006). Density and relative frequency effects on competitive interactions and resource use in pea barley intercrops. Field crops Journal, 95, 256-267. http://dx.doi.org/10.1016/j.fcr.2005.03.003

Hegstad, J. M., Bollero, G., \& Nickel, C. D. (1999). Potential of using plant row yield trials of predicting soyabean yield. Crop science, 39, 1671-1675. http://dx.doi.org/10.2135/cropsci1999.3961671x

Hiebsch, C., Tetio-kegho, F., \& Chirembo, F. P. (1995). Plant density and soya bean maturity in maize soya bean intercrop. Agro. J., 87, 965-970. http://dx.doi.org/10.2134/agronj1995.00021962008700050032x

Hussaini, I, M., Baloch, S., \& Sayal, O. (2001). A field study of Sorglum CV. G.263 grown alone or intercropped with cowpeas. Journal of Agriculture, 15- 41, 317-328

Jaetzold, R., \& Schmidt, H. (1982). Farm management handbook of Kenya (Vol. 2, pp. 397-400). Nairobi: Ministry of Agriculture.

Jayanyama, D. K., Bell, J. C., \& Sale, P. W. (2001). Modification of within canopy microclimate in maize intercropping in tropics. J. Agro Res Tropics, 2, 1020-1024.

Kumar, J. (2000). Pulses: Towards a qualitive leap. Hindu survey of Indian Agriculture, 49-52.

Liebman, M., \& Davis, A. S. (2001). Integration of soil, crop and weed management in low input farming systems. Weed Res, 40, 27-47. http://dx.doi.org/10.1046/j.1365-3180.2000.00164.x

Matusso, J. M., Mugwe, J. N., \& Mucheru-muna, M. (2013). Effects of different maize (Zea mays L.) -soybean (Glycine $\max$ (L.) Merrill) intercropping patterns on yields and land equivalent ratio. Academic J., 4(4), 48-57.

Mohammed, D. B., Olufujo, O. O., \& Singh, B. (2009). Growth and development of components of sorghum and cowpea intercropping in Northern Nigeria. APRN Journal of Agricultural and Biological Science, 3(3), 7-13.

Naser, A. S., \& Shamsaddin, S. M. (2008). Effects of plants densities and row orientation on seed and forage yield of sorghum. Isfahan univ, 12(45), 91-97.

Ndekidemi, A. P., \& Makoi, J. R. (2007). Effect of plant densities and cropping systems on yield of cowpea genotypes and sorghum. Journal of Tropics Agriculture, 48(1-2).

Nkongulo, K. K. (2003). Genetic characterization of Malawian cowpea landraces, diversity and Gene flow among accessions. Euphytica, 129(2), 219-228. http://dx.doi.org/10.1023/A:1021935431873

Ofari, F., \& Stern, W. R. (1987). Cereal - legume intercropping systems. Adv.agron, 41, 41-90. http://dx.doi.org/10.1016/S0065-2113(08)60802-0

Oseni, T. O. (2010). Evaluation of Sorghum-Cowpea Intercrop Productivity in Savanna Agro-ecology using Competition Indices. Journal of Agricultural Science (1916-9752), 2(3).

Raghuwansi, R. K., \& kushwaha, S. S., Gantam, V. S., \& Sharma, N. K. (2002). Chemcial composition nutrient uptake and yield in sorghum-soya intercrop. Crop Research, 24(3), 453-457.

Saidi, M., Ngouajio, M., \& Ituya, F. M. (2007). Leaf harvesting initiation time and frequency effect biomass partitioning and yield of cowpea. Crop science, 47, 1159-1166. http://dx.doi.org/10.2135/cropsci2006.06.0420

Salasya, B., Obendo, M., \& Ondenya, J. (1996), Adoption of improved sorghum varieties and other productions technologies in Busia, Kenya. Proceedings of $5^{\text {th }}$ KARI scientific conference. $14^{\text {th }}-16^{\text {th }}$ Oct. 1996 KARI Nairobi Kenya.

Saleem, R., Ahmed, Z. I., Malik, M. A., \& Khan, M. A. (2011). Response of maize-legume intercropping to different fertility sources under the rainfedconditions. Sarhad. J Agric., 27(4), 503-511.

Silwana, T. T., \& Lucas, E. O. (2002). Effect of planting combinations and weeding on yield components of maize and beans and maize and pumpkin intercrops. J. Agric. Sci., 138, 193-200. 
Subian, P., \& Selvaraju, R. (2000). Effect of row ratio on sorghum and soyabean intercropping system in rainfedvertisols. Indian Journal of Agro., 45, 526-529.

Sullivan, P. (2003). Intercropping principles and practices. Agronomy systems guide science, 188, 212-218.

Tsubo, M., Mukhala, E., Ogindo, H. O., \& Walker, S. (2004). Productivity of maize-bean intercropping in a semi-arid region of South Africa. Water SA, 29(4), 381-388. http://dx.doi.org/10.4314/wsa.v29i4.5038

Zhang, H., Pala, M., Oweis, T., \& Harris, H. (2000). Water use and water-use efficiency of chickpea and lentil in a Mediterranean environment. Crop and Pasture Science, 51(2), 295-304. http://dx.doi.org/10.1071/AR99059

\section{Copyrights}

Copyright for this article is retained by the author(s), with first publication rights granted to the journal.

This is an open-access article distributed under the terms and conditions of the Creative Commons Attribution license (http://creativecommons.org/licenses/by/3.0/). 